\title{
Economic mechanism of ensuring the sustainability of the healthcare subsystem in the socio-economic system of the region
}

\author{
Evgenii Gradoboev ${ }^{1, *}$, and Irina Solskaya ${ }^{2}$ \\ ${ }^{1}$ ISMAPgE Branch Campus of the FSBEI FPE RMACPE MOH Russia, Yubileiny, 100, 664049 \\ Irkutsk, Russia \\ ${ }^{2}$ Irkutsk State Transport University, Chernishevsky Str., 15, 664074 Irkutsk, Russia
}

\begin{abstract}
The study of the problems of sustainable development of regions is of particular importance in the context of socio-economic instability caused by the influence of non-systematic risks of the epidemiological situation in the Russian Federation. The analysis showed that in modern science there is still no generally accepted understanding of the priority of measures aimed at sustainable development of the economy and society, since the scale of the modern challenge to sustainable development can be assessed only after a certain time has passed. measures taken to maintain sustainability must be taken in real time. The priority of such measures is due to the current directions of development of the entire socio-economic system of the Russian Federation, implemented within the framework of state target programs. In the article, from the entire set of socio-economic problems, the problems of health care are highlighted, due to its universality and versatility of the issues under consideration.
\end{abstract}

\section{Introduction}

From the standpoint of theoretical studies, stability is considered as a fundamental property of the system $[1,2]$, moreover, the consideration of stability as a fundamental property of systems (V.V.Artyukhov, V.G. Vinogradov, A.S. Martynov) allows priority of stability factors from the standpoint of the structure of the system.

The authors believe that considering the country as a system implies that three subsystems can be distinguished in its structure: society, material and technical complex and natural resources, while the sustainability of development is characteristic of each of them. "Social health" is defined as one of the most important resources.

A number of Soviet scientists [3] determined the stability of society, for example, through the ability of residents of a particular territory to maintain their well-being and ensure the development of productive forces.

G.V. Gutman, A.A. Miroedov, S.V. Fedin in his work opposes stability to the crisis state and through the description of this opposition go out to determine the stability of the socio-

\footnotetext{
${ }^{*}$ Corresponding author: gradoboev_eugene@mail.ru
} 
economic development of the region. The authors highlight the most important functional characteristic of the region: "the ability to function as a self-developing system is" [4].

In the list of indicators of sustainable development of the territory, which determine the main forms of security - social, economic, environmental V. Vasilenko emphasizes the special place of health care as a subsystem playing a leading role in ensuring the social security of the territory [5].

For many years, health care in the studies of Soviet and Russian scientists was defined as a branch of the non-production sphere, which is characterized by the expenditure of budgetary funds, without participation in the formation of the national product.

Today, this point of view is being rethought, which finds its disclosure not only in scientific, but also in educational literature.

According to M.G. Kolosnitsyna, I. M. Sheiman, S. V. Shishkin [6], a distinctive feature of the healthcare industry is the variety of funding sources for medical services and, as a consequence, the diversity of the models of financing medical organizations that provide the population with - medical assistance. Along with state funding through the budgetary financing system or the compulsory health insurance system, medical organizations receive funds directly from citizens for the provision of paid medical services, or indirectly under voluntary health insurance contracts concluded either by the patients themselves or by employers in the benefit of their employees. Rizvanova M.A. in the dissertation research notes that the variety of modern financing mechanisms is reflected in the distribution of resources in the industry [7].

S.A. Livshits [8] emphasized that the definition of an effective economic mechanism of financing is the most important task solved by health care in modern socio-economic conditions and the solution of this problem is aimed primarily at providing the necessary financial resources to satisfy the population in providing medical help. Providing the health care industry through a variety of economic financing mechanisms with the necessary resources is an important and difficult task, the solution of which is achieved, among other things, through state regulation.

\section{Materials and Methods}

In the present study, the study used the methods of expert assessment, synthesis, deduction and induction, economic, historical, logical, systemic and comparative analysis. Consideration of the problem of choosing and implementing an effective mechanism for financing health care presupposes an assessment of the existing theoretical approaches to the content of the term "economic mechanism" [9].

The Center for Strategic Development and the Higher School of Economics prepared a joint report: "Healthcare: Necessary Responses to the Challenges of Time" [9], the content of which includes a description of the sequence of implementation of measures to improve the efficiency of healthcare financing. The report also notes the need to change the funding model, taking into account the strategic goal of increasing the level of motivation of participants.

For the implementation of the task, the researchers propose a certain sequence, consisting of two main stages. First of all, it is proposed to increase the validity and objectivity of the distribution of state financial resources for health care with the obligatory observance of the conditions for the transparency of their use. After the implementation of the first stage, market regulation mechanisms should be included, namely, competition between medical organizations working in the field of compulsory health insurance for appropriate financial resources. All this should be accompanied by the improvement of methods of payment for medical care, which should be based on insurance principles. For the implementation of the 
proposals, it is proposed in a pilot mode in several constituent entities of the Russian Federation to test new financing mechanisms for medical organizations working in the field of compulsory health insurance.

The resources required for this should be mostly increased in 2024 in relation to 2017 in terms of the cost of salaries for medical workers, the level of which is determined by the Decree of the President of the Russian Federation No. 597 of 05/07/2012 [10] - by 20\%, as well as by drug provision - by $15 \%$ [9].

For a reasonable choice of the mechanism for financing health care as the basis for increasing the efficiency of the industry, it is necessary to consider the content of the concept of "economic mechanism" [11]. Theoretical approaches to the options for the implementation of the three main economic mechanisms are presented in Table 1.

Table 1. Theoretical approaches to the content of the term "economic mechanism"

\begin{tabular}{|c|c|c|c|}
\hline $\begin{array}{l}\text { Author, source } \\
\text { of information / } \\
\text { Comparison } \\
\text { criteria }\end{array}$ & $\begin{array}{ll}\text { Burkov } & \text { V.N., } \\
\text { Novikov } & \text { D.A., } \\
\text { Schepkin A.V. } & \\
\text { Kulman A. }[12,13]\end{array}$ & Hurwicz L. [14, 15] & Chaadaev V.K. $[16,17]$ \\
\hline $\begin{array}{l}\text { I. Approach to } \\
\text { the essence of } \\
\text { the "economic } \\
\text { mechanism" }\end{array}$ & $\begin{array}{l}\text { "Economic } \\
\text { mechanism" as a tool } \\
\text { for managing objects }\end{array}$ & $\begin{array}{l}\text { "Economic mechanism" as } \\
\text { a tool for interaction } \\
\text { between subjects. }\end{array}$ & $\begin{array}{l}\text { "Economic mechanism" as a } \\
\text { certain sequence } \\
\text { interconnected of } \\
\text { phenomena, which is objective } \\
\text { and can explain some natural } \\
\text { evolutionary process of the } \\
\text { development }\end{array}$ \\
\hline $\begin{array}{l}\text { II.Control } \\
\text { model }\end{array}$ & $\begin{array}{l}\text { A complex of } \\
\text { activities coordinated } \\
\text { by performers, terms } \\
\text { and resources, } \\
\text { providing an effective } \\
\text { solution to the } \\
\text { problems } \\
\text { managing of } \\
\text { economic system. }\end{array}$ & $\begin{array}{l}\text { A tool for interaction } \\
\text { between subjects. }\end{array}$ & $\begin{array}{l}\text { A sequence of objective } \\
\text { interrelated economic phenomena }\end{array}$ \\
\hline $\begin{array}{l}\text { III.The } \\
\text { objective } \\
\text { function. }\end{array}$ & $\begin{array}{l}\text { The indicators of the } \\
\text { objective function are } \\
\text { estimated by } \\
\text { numerical values, } \\
\text { based on reports. }\end{array}$ & $\begin{array}{l}\text { An action plan that defines } \\
\text { the steps to achieve the } \\
\text { goals }\end{array}$ & $\begin{array}{l}\text { Optimal selection of functional } \\
\text { system elements }\end{array}$ \\
\hline $\begin{array}{l}\text { IV.Center } \\
\text { (block) of } \\
\text { control. }\end{array}$ & $\begin{array}{l}\text { Determines the rules } \\
\text { for the functioning of } \\
\text { the system. }\end{array}$ & $\begin{array}{l}\text { Develops and defines the } \\
\text { requirements for the } \\
\text { subjects of the system }\end{array}$ & $\begin{array}{l}\text { A sequence of interrelated } \\
\text { economic phenomena. }\end{array}$ \\
\hline $\begin{array}{l}\text { V.Execution } \\
\text { control } \\
\text { methods }\end{array}$ & Road map. & $\begin{array}{l}\text { Incentives for the effective } \\
\text { impact of the center on the } \\
\text { subjects, based on the } \\
\text { assumption of the rational } \\
\text { behavior of the subjects }\end{array}$ & $\begin{array}{l}\text { The system-forming role of } \\
\text { information flows is taken into } \\
\text { account, which characterize the } \\
\text { degree of uncertainty, which, in } \\
\text { turn, controls the rational } \\
\text { behavior of subjects. The } \\
\text { imbalance of information flows, } \\
\text { that is, when the participants in } \\
\text { the interaction have different } \\
\text { information about each other, } \\
\text { leads to a violation of the } \\
\text { economic laws. }\end{array}$ \\
\hline $\begin{array}{l}\text { VI. Control } \\
\text { object }\end{array}$ & $\begin{array}{l}\text { A set of resource- } \\
\text { related activities }\end{array}$ & $\begin{array}{l}\text { A set of objects related by } \\
\text { the general nature of } \\
\text { activity. }\end{array}$ & $\begin{array}{l}\text { Information flow of participants } \\
\text { about each other, based on the } \\
\text { assumption of the rational } \\
\text { behavior of subjects on the basis } \\
\text { of incoming information }\end{array}$ \\
\hline
\end{tabular}




\begin{tabular}{|c|c|c|c|}
\hline \multicolumn{4}{|c|}{ Table 1. Continued } \\
\hline $\begin{array}{l}\text { VII. Functional } \\
\text { block }\end{array}$ & $\begin{array}{l}\text { Motivational and } \\
\text { incentive control } \\
\text { actions. }\end{array}$ & $\begin{array}{l}\text { Controlling impact: } \\
\text { competition, inflation } \\
\text { rates, government policy, } \\
\text { etc. Motivational and } \\
\text { incentive control actions. }\end{array}$ & $\begin{array}{l}\text { Economic cycle mechanisms, } \\
\text { multipliers }\end{array}$ \\
\hline $\begin{array}{l}\text { VIII. Viability, } \\
\text { effectiveness } \\
\text { of the } \\
\text { approach }\end{array}$ & $\begin{array}{l}\text { Viability and } \\
\text { practicality largely } \\
\text { depends on various } \\
\text { kinds of assumptions } \\
\text { and limitations } \\
\text { imposed on the } \\
\text { ability of the object. }\end{array}$ & $\begin{array}{l}\text { The interaction of subjects } \\
\text { is limited to the sphere of } \\
\text { their interests, and is } \\
\text { implemented at the level } \\
\text { of sectors of the economy, } \\
\text { as well as other } \\
\text { associations of subjects. }\end{array}$ & $\begin{array}{l}\text { Эффективность определяется } \\
\text { степенью вероятности } \\
\text { реализации интересов } \\
\text { субъектов. }\end{array}$ \\
\hline
\end{tabular}

\section{Results and Discussion}

The approbation of the research results was carried out on the example of assessing the mechanisms of interaction of the main parties that ensure the solution of urgent problems of preserving the health of the population, the action of a specific mechanism of economic interaction was shown, the nature of their development was determined. The issues of health care efficiency as a condition for the stability of the system were considered, first of all, from the standpoint of the economic security of the region [18].

An analysis of the practice of financing the regional health care system of the Irkutsk region showed that health care financing is carried out at different levels of management with the implementation of signs of several economic mechanisms:

1. Within the framework of the implementation of the State Program "Development of Health Care" [19], the amount of budgetary allocations for its implementation at the expense of the federal budget has been determined.

In accordance with the features of the first approach, target indicators and indicators have been established to assess the effectiveness of its implementation, including: population satisfaction with the quality of medical care, mortality of the working-age population, including from certain classes of diseases, life expectancy, etc.

2. Elements of the second economic mechanism are being implemented. As an example, the execution of the funds of the normalized insurance stock of the territorial compulsory medical insurance fund (hereinafter referred to as the NIR TCHIF) for the purchase, repair of medical equipment and training of medical workers [20] can serve.

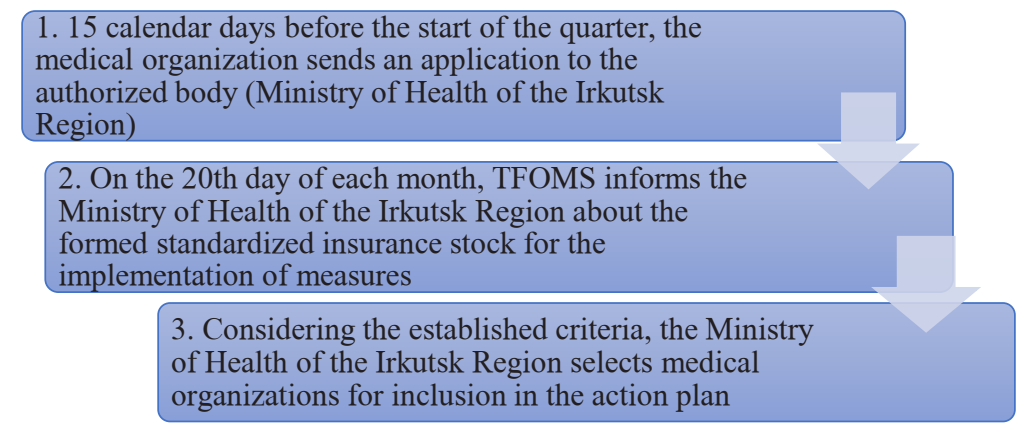

Fig. 1. The mechanism for forming an action plan 
3. At the same time, within the framework of the same resolution, the elements of the third mechanism are implemented, due to the specifics of information flows of the control object (Fig. 2).



Fig. 2. The mechanism of bringing NIR funds to a medical organization

\section{Conclusions}

Taking into account the above, we will formulate the assumption that the existing diverse structure of health financing mechanisms is a fundamental factor ensuring the development of socio-economic systems, increasing its efficiency of functioning, as well as sustainability.

\section{References}

1. Neck R., IFAC Proceedings Volumes, 16 (12) 527 (1983)

2. Iis Nurasiah, Nugraha Nugraha, Disman D. Rozmita Dewi Y.i, Kharisya A. E., United States International Journal of Energy Economics and Policy, 10(5), 58 (2020)

3. Martynov A.S., Artyukhov V.V., Vinogradov V.G., Russia as a System: Comprehensive Analytical Web-Atlas (1977)

4. Gutman G.V., Miroedov A.A., Fedin S.V., Regional Economy Management. Moscow: Finance and Statistics, 16 (2002)

5. Vasilenko V.,Standards and quality, 3, 24 (2001)

6. M. G. Kolosnitsyna, I. M. Sheimna, S. V. Shishkin, Health economics. Higher School of Economics, 479 (2008)

7. Rizvanova M.A., Improving the financing of the health care system as a factor in the growth of the human potential of the region (on the example of the Republic of Bashkortostan) (2006)

8. Livshits S.A., Features of financial resources management in treatment and prevention organizations of various forms of ownership (2003) http://medical-diss.com/medicina/ 9. What Russian healthcare should be like. Scientific report, (2018) https://www.csr.ru/ 10. Decree of the President of the Russian Federation No. 597 of May 7, 2012, On measures for the implementation of state social policy (2012) http://base.garant.ru/70170950/

11. Zhuravlev, D.M., Kreativnaya ekonomika, 13(2), 249 (2019) 
12. Burkov V.N., Novikov D.A., Schepkin A.V., Management mechanisms for ecological and economic systems, 244. (2008)

13. Kulman A., Economic mechanisms, 188 (1993)

14. Hurwicz L., Reiter S., Designing economic mechanisms (2008)

15. Hurwicz L., Papers and Proceedings of the Eighty-fifth Annual Meeting of the American Economic Association, 63 (2), 1 (1973)

16. Chaadaev V.K., Scientific and technical statements of the St. Petersburg State

Polytechnic University. Economic sciences, 3 (48), 115 (2006)

17. Chaadaev V.K., Innovative and investment technologies for reengineering enterprises communication and informatization: abstract of dissertation on the competition. uch. Art. (2007).

18. Gorbunov Yu, Gorbunova A., Solskaia I., IOP Conference Series: Earth and Environmental Science, 395 (1) (2019)

19. State program "Development of health care" Approved by the Resolution of the Government of December 26, 2017 No. 1640. The current edition of the state program "Development of health care" (2017)

20. Decree of the Government of the Russian Federation of April 21, 2016 No. 332 "On approval of the Rules for the use by medical organizations of funds from the standardized reserve stock of the territorial compulsory health insurance fund for financial support of measures for organizing additional professional education of medical workers under qualifications, as well as the purchase and repair of medical equipment, (2016) https://www.garant.ru/ 